$\mathbb{P}$ periodica polytechnica

Architecture

40/1 (2009) 37, 46

doi: 10.3311/pp.ar.2009-1.05

web: http://www.pp.bme.hu/ar

(c) Periodica Polytechnica 2009

RESEARCH ARTICLE

\section{Authenticity and didactics: theory and practice in the preservation of our medieval monuments}

\author{
Ákos Zsembery
}

Received 2008-03-28

\begin{abstract}
Nowadays one of the much discussed pivotal points in the preservation of monuments, especially in the case of ruins, are about the charters, i.e. can such theoretical and subjective concepts like authenticity, monument value or restoration be used uniformly and what these phrases exactly stand for? In my analysis I observed and analysed the historical state of the medieval type churches and monasteries around my home area, in Komárom-Esztergom County. Since most of the visited architectural monuments are left as remains, throughout their monumental preservations we could analyse, from a practical point of view, our theories on the restoration of historic buildings. A special viewpoint and method is required for the analysis and restoration of ruins. The tools of architecture differ in the case of the restored buildings and ruins, since in the former case a thoroughly new architectural creation is established during the restoration process, by using only the material and the imagined form of the original monument. On this basis, we can state, that the basic needs of restoration are credibility and representation, so simply, these should be analysed within the framework of authenticity and didactics.
\end{abstract}

\section{Keywords}

monument preservation $\cdot$ conservation of ruins $\cdot$ medieval monuments

\section{Ákos Zsembery}

Department for History of Architecture and of Monuments, BME, H-1111 Budapest Múegyetem rkp. 3., Hungary

e-mail: zsembery@et.bme.hu

\section{Introduction}

The principles and methods for the modern protection of monuments are becoming fundamental subjects in architectural history just like the reconstructed or to be reconstructed monuments. The more regularly emerging professional arguments in the aspect of this professional subject show that it is time to take an overview and look at the modern protection of historical monuments. From several different aspects, this is indispensably necessary. On one side this helps us to recognise the occurring future problems, while on the other it is essential for the correct analysis of future solutions.

As the lately deceased Mr. János Sedlmayr said: "amongst other things, the objective, later analysis and reviews also help in the correct reconstruction of architectural memories in practice" [8]. Naturally reckoning is a longer process, which becomes even more difficult when one considers the varied state, and age of the built heritage in different areas. Since a different approach and method is needed for an ancient, a medieval or a modern aged monument, in particular if the given country's economic, historical and nowadays it's political areas are taken into consideration. For a successful understanding, initially, the domestic and the European practices should be objectively analysed and compared, then the following question should be answered: how should we protect our monuments in the present economic and natural condition 11 I believe this new revised claim differs from what the so called "post-modern argument" has created ${ }^{2}$

What method shall we use to reach our goals? To answer the arising question, we have to be acquainted in detail with the processing work; i.e. a continuously updated organic database should be available, which contains not only the existing or badly demolished buildings but summarises all reconstructions. This task, which extends to the analysis of monuments' afterlife, is still to be done. Perhaps as the secondary product of such an overall work, it could bring the monumental topography to fruition ${ }^{3}$ If monument preservation reveals monuments' after-

\footnotetext{
${ }^{1}$ The lately published memorandum of Vienna reveals this most effectively.

${ }^{2}$ As Mr. Miklós Horler could, regarding the questions of post-modern and protection of monuments. See [2]

${ }^{3}$ This is owned by the Hungarian Protection of Monuments. The newest
} 
life, it may give an opportunity for systematising and analysing renovation works, which could then lead to its theoretical review; obviously it should initially be carried out in a domestic environment.

Nowadays one of the pivotal argument points is about the charters, i.e. can such theoretical and subjective concepts like authenticity, monument value or restoration be used uniformly and what these phrases exactly stand for? The distinctiveness of the Hungarian monument substance provides the charter of restoration or in other words the Venice Charter (1964) to be atoned in the Hungarian monumental restoration, unlike in other Western European countries. Only with the completed work and with the knowledge of its conclusions will we be able to get an objective answer to this question.

It is not possible within this article to develop a new methodology, but ;n the basis of the following case study presentations, I will try to point out the possible options and solutions, while providing some new information for the compiled work, which needs to be carried out as soon as possible.

\section{The Subject and the Original Methods of the Survey}

This subject is viewed within the aspect of the medieval type church monument. This model may help in the completion of the previously mentioned and necessary monumental topography.

Throughout my analysis I observed and analysed the historical state of the medieval type churches and monasteries around my home area, in Komárom-Esztergom County ${ }^{4}$ architectural monuments are left as remains, throughout their monumental preservation we can analyse, from a practical point of view, our theories on the restoration of historic buildings.

In the present article I am going to analyse the monument preservation of 15 medieval type buildings in different states and quality. Naturally, for instance in the case of Esztergom, more medieval type building sites are known, however these have not yet been excavated. On the basis of the condition of the medieval elements, we can arrange the analysed restorations into several groups: buildings with several restorations but mainly in their medieval state; mainly restored monuments; monument remains. The last category may be further grouped as: remains in urban areas and in their natural environment.

A special viewpoint and method is required for the analysis and restoration of ruins. Tools of architecture differ in the case of ruins and restored buildings, since in the latter case a thoroughly new architectural creation is established during the restoration process, by using only the material and the imagined form of the original monument.

The question of the material used during the restoration and

volumes of the topography are many decades old. Unfortunately Hungary has not extensively published smaller summaries of monumental topographies (the "Dehio type").

4 A monumental topography for Komárom County has never been created. For a list of monuments and detailed introduction see: [11 the reversibility of the process raise further points for debate, however other basic problems occur during such a preservation, i.e: determining the correct level of restoration, creating a clear and an understandable preservation for the public, (which I believe by the way is one of the most important criteria). Viability of restoration is also an indispensable issue to analyse, since in the case of the so called "dead" monument we have to find a real function. Throughout the history of the protection of monuments the problem of a lack of function was simply solved by assimilating the original monument into the modern conception 5

In the case of the heavily restored medieval type monuments, medieval elements lose their privileged places, since the protection and preservation of the latter established layers become just as important. So we can conclude that these different aged but equally valuable elements should be preserved together. This question has caused just as many problems and arguments as the completion of the remains 6 since the basic rule of preservation orders primarily emphasise the most valuable elements. So we can state, that the basic needs of restoration are credibility and representation, and that these should be analysed within the aspects of authenticity and didactics.

\section{Authenticity and didactics}

On the basis of the two terms referred to in the subtitle, we are going to analyse monument restorations; but first I believe we should define these phrases in detail, since they frequently cause many arguments.

Possibly the most important aspect in monument preservation is authenticity. In November 1944, a special conference was organized in Japan in order to clarify the definition of authenticity, but even the "Nara Documentation" which was established during the seminar, does not contain its exact definition.

Before the Japanese conference, Hungarian professors held a symposium to determine the domestic viewpoint on this concept. The differences of opinion had already appeared here, a fact that needs to be considered during the analysis of such a difficult question. Even now there are no general, overall works, which clarify and determine all aspects of the definition of authenticity. Apart from the written documents of this domestic conference 7] the candidate study [4] of Professor Tamás Mezôs was a good attempt in 1994. One of the most essential tasks of previous decades was to establish the correct and complex definition of this phrase. During the analysis of concrete examples I will try to develop a summary definition within this present dissertation.

As Mr. Tamás Fejérdy stated, monumental heritage is the value, which is supported by authenticity. Authenticity can not be explained on its own; it is an analogue definition which can be classified as the following: "material, form and essence, whose

\footnotetext{
5 See 67 7

6 [9] János Sedlmayr, a well known monument reconstructor has published many essays on this subject.

${ }^{7}$ See: [5]
} 
strength is determined by cultural differences, 8 so we can not classify one general idea. In spite of this, it should not be used subjectively, and transformed in different cultures [1].

Professor Tamás Mezôs defined authenticity on the basis of the European concept and the comparison of several preservations: "I consider the most important criteria of restoration is visual authenticity. I believe the connection between the original and the restored remains presents authenticity in architecture, in material and in principles." [4], (pp 111) If the preservation of medieval ruins is involved in the present structure of the organically developed city, authenticity also represents the closer environment of the monument. All of these statements are true regarding authenticity but it is specific to each monument analysis.

To define the idea of didactics is easier. This is basically the method of the authentic preservation of a given monument's remains. Consequently if authenticity is based on the theoretical criteria of the material and the intangible value of a given monument, then didactics is the practical side. Didactics is not a pile of written methods, but the continuously changing tools of solutions used during restoration. Even though didactics has no documented rules, in practice it has its own regulations. The chosen process should depend on the given monument.

\section{The analysis of actual restorations}

The following buildings that have been assessed may be grouped accordingly:

- Restored multi-period existing buildings: Bajna, Bajót, Bakonybánk, Csatka, Lábatlan, Neszmély, Tata, Esztergom: Castle chapel;

- Reconstructed remains in their natural environment: Dömös, Klastrompuszta, Pilisszentlélek, Vértesszentkereszt;

- Remains excavated in the urban environment: Esztergom: Kovácsi church, Esztergom: Johannita convent, Esztergom: St. Lawrence church.

Introducing the history and the medieval elements of the analysed buildings in detail is not possible 9 within this article, and from the point of our survey it is not necessary.

In the case of buildings containing medieval elements, in spite of several restorations, the original medieval mass should be emphasised next to the later established uniform mass. This forces architects to compromise, which could lead to the general use of didactical elements. The possible solutions for problems occurring during the preservation of the buildings can differentiate and change the quality of monument preservation.

\section{Bajna}

The currently standing St. Adalbert Catholic Parish Church contains a significant amount of remains of the original monument from the XV century. Although the church was rebuilt

\footnotetext{
${ }^{8}$ The so called Ise-argument had the same source.

${ }^{9}$ For detailed preservation of the monument, see [11].
}

twice, the preservation of its medieval values and areas is successful. During the reconstruction process, the different aged parts of the building were painted different colours, so the original and the later restored elements are clearly (and visually) separated from each other. The two western pillars show the original length of the medieval building. The old western gate of the new church would have been out of place, so it was rebuilt into the south side aisle, as the in situ entrance of the northern sacristy was presented as a decoration of the present building. Inside the church, next to the original renaissance ciborium, the previously mentioned sacristy door and the two gothic windows on the south wall of the sanctuary were located. Although their sections are thickly whitewashed; their colour does not differentiate them from the wall.

The outside is not so uniform, while the brick completion of the buttresses is a nice solution, the brick surface of the gothic windows is out of place. The original window frame should not have been built in, especially in the case of the eastern window where the surface was completed with stone. It is interesting to note, that only two of the sanctuary's windows are shown. We have no information about the third one. Two smaller windows are possibly the result of the modern restoration, but we cannot find any information or theoretical reconstruction drawings on the building. To conclude, the original and the restored parts are well separated didactically; the view of the monument is authentic and it is easily understandable by the public.

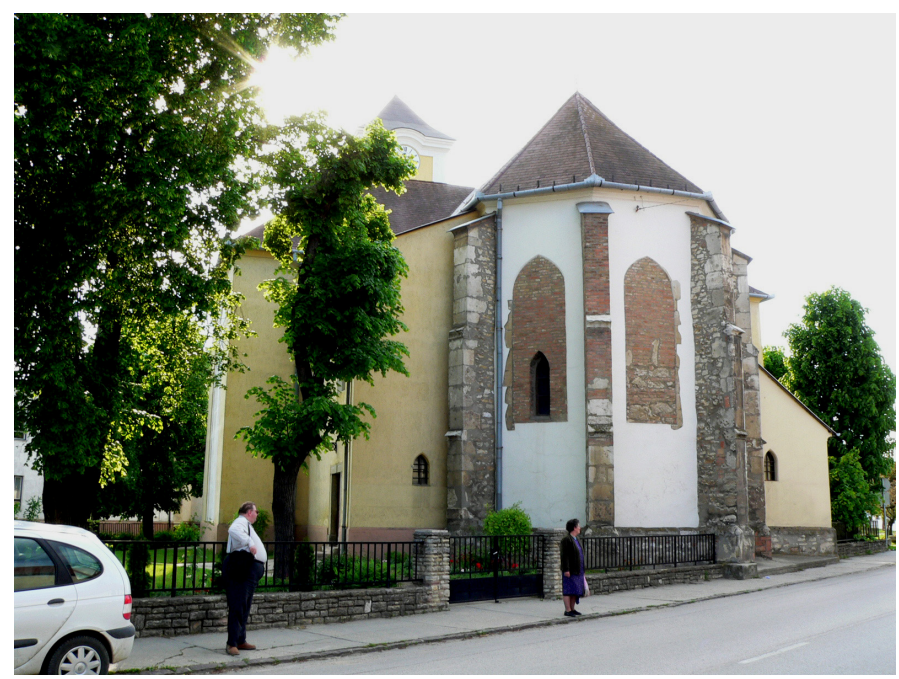

Fig. 1. The View of the Church of Bajna

\section{Bajót}

The Catholic Parish Church of St. Simon and Judas stands on top of a hill in the middle of the community. Some parts of the nave and the tower were built in the XIII century. The archaeological topography concludes, from the shape of its sanctuary and from the fact that it was used during the XVII-XVIII century, that the base of the east side and the sanctuary was originally built in the XIV-XV century [3].

During later restorations, the church was not extended, so it 
kept its original medieval size. The medieval elements are visually -with the same whitewash but differentiated by their surface - separated from the latter restored parts. It is slightly disturbing though that this method was not used on the tower, even though its mass, its corner buttresses and its window frames depict its medieval origin. The preservation of the revealed original gothic styled doorway with console on the northern side of the tower, the upstairs loophole and the twin windows are more detailed than in the case of the Bajna church. The colour and the material of the surfaces are the same; the different levels are shown only by the size of the windows and although the yellow coloured base of the church breaks up the small units, they are well presented by clear surface differentiation. Compared to the example earlier, this restoration work is more elaborate, so a more uniform medieval building has been restored using the detailed preservation techniques that were required. Theoretically and in practice this is one of the best examples of correct monument preservation.

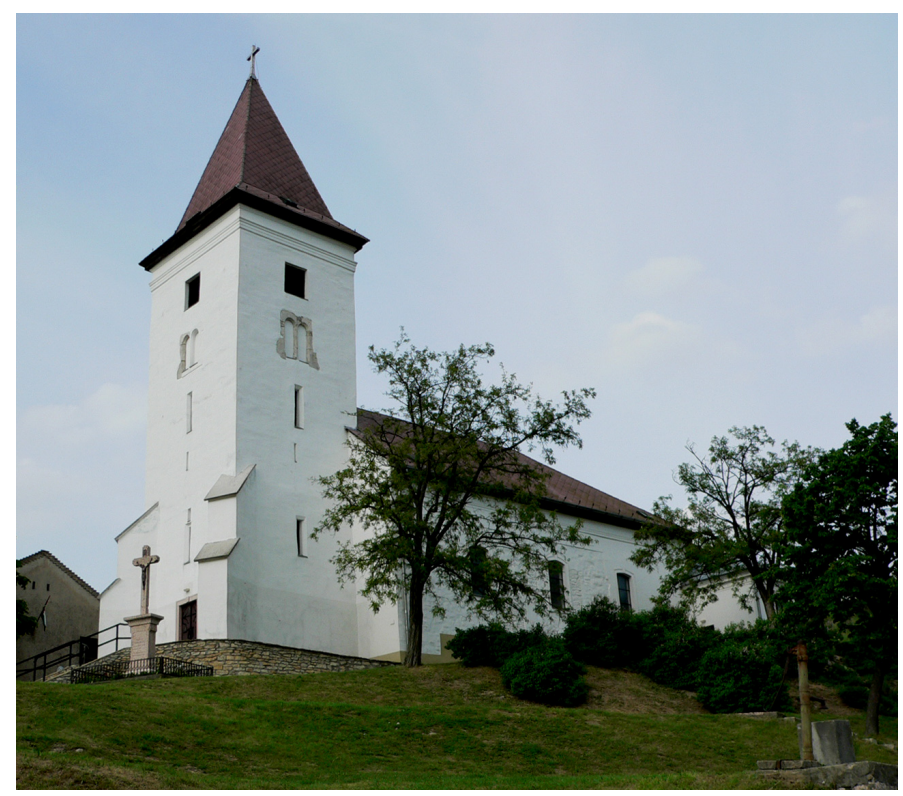

Fig. 2. The Church of Bajót

\section{Bakonybánk}

Not much information has been left regarding this church. All that we know is that it was built sometime in the XV century, and burnt down in 1870. During the restoration works in 1900, its nave, the flat ceiling of its sanctuary and the tower was rebuilt. Only the buttresses of the sanctuary show its medieval character. The measurements and ground plan of the church render the fact probable that the church was rebuilt on its original, medieval base. If its sanctuary had any windows, is not shown. At the time of my visit, the church looked rather desolate: its gate was ajar and no visitors were there apart from me. With a detailed examination, any remaining original features could be re-established, and then be preserved.

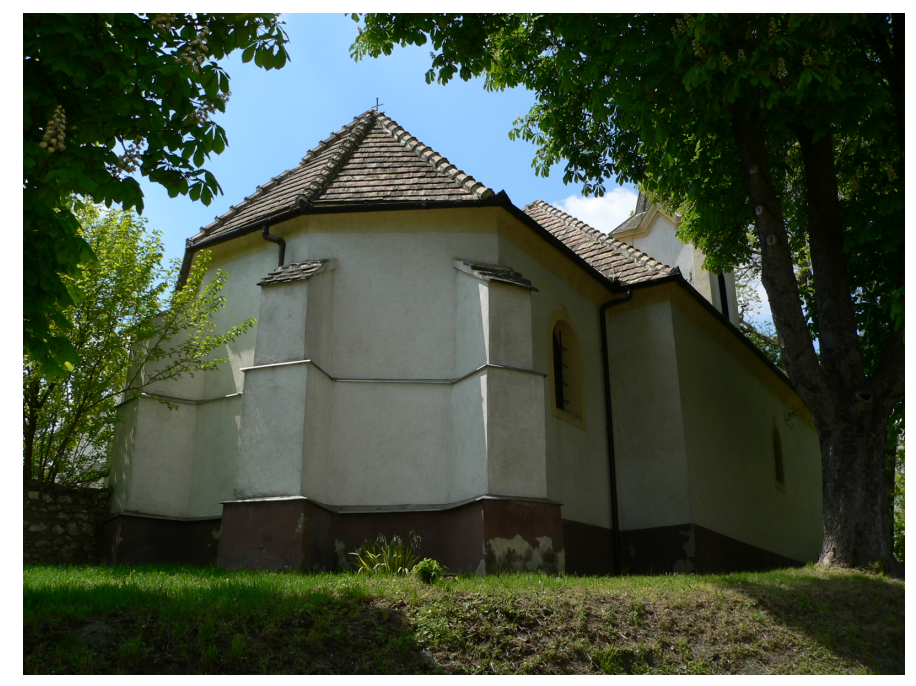

Fig. 3. The Church of Bakonybánk

\section{Csatka}

The Catholic Church of the Visitation hides the earlier built St. Paul's church - the best condition of any medieval internal space in the county. It is also interesting to see its ground plan and structural approach since this process was only used at the Tüskevár St. Paul's Church, which has since been demolished. The demolished church was left in ruins for more than two centuries; later in 1780 it was rebuilt in late baroque style. Its restoration and monumental values were presented between 1966 and 1968.

The preservations of the original elements are well presented in the inner area. The medieval elements are clearly emphasised, and even with the lower arched baroque styled area it has an organic feel. Unfortunately the restoration of the renaissance gravestone on the north wall of the sanctuary was not well done; additionally the flowers placed on the top, cover the relief. Even such minor things can disturb or ruin the preservation of the original elements. On the outside of the church the original stone surface is clearly shown at the corners and buttress of the building. In such cases the differentiation of the original wall surface can not be observed. It is not clear which of the unique square stones are presented. The unified appearance of the original medieval ornament is given by the simple coloured wall surfaces both inside and out. Unfortunately the greenery and trees of the small southern garden hides the south wall's medieval elements and this disturbs the whole view of the building. Although this problem could be easily solved by removing the trees.

\section{Esztergom Castle Chapel}

The palace of King Béla III is one of the gems of European architecture. It was built between 1185 and 1205, which means it is one of the first gothic styled buildings outside France. After its reveal, the building and its frescos were restored between 1934 and 1938 and then in 1968. Until recently no reconstruction work has been carried out. Its professional restoration is 


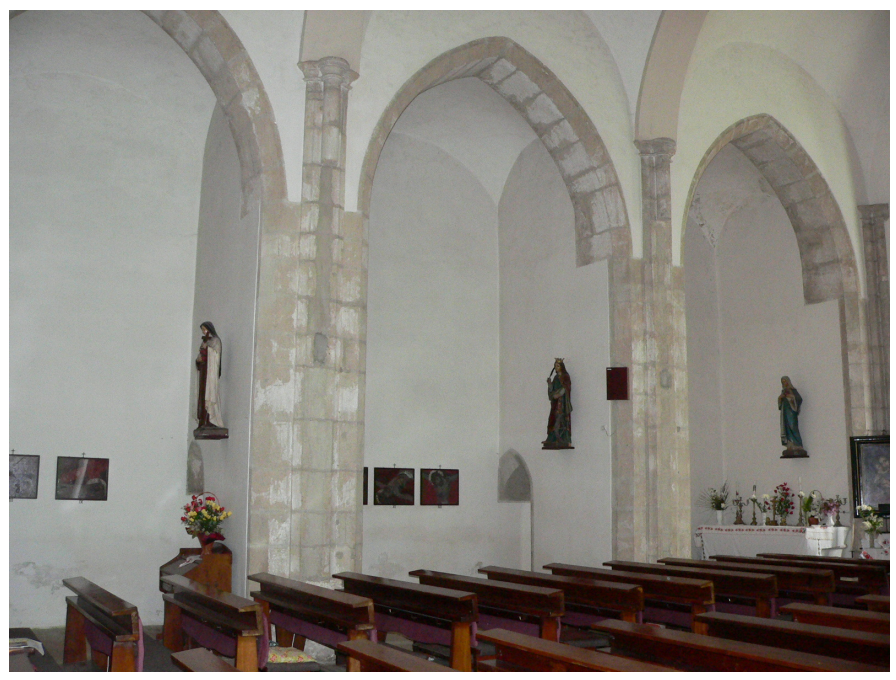

Fig. 4. The Church of Csatka

still ongoing.

Its western front gate and nave, up to half of its height, are in their original state. The chapel restored by anastylosis is still a key example of the Hungarian monument preservation executed between 1934 and 1938. During the Lux-Várnai restoration many pieces of its frescos were not replaced. Into the uniform brick surface used at its completion, stone copies were placed sporadically. The original painted elements are now in the process of restoration and replacement. After the work of Zsuzsa Wierdl and her international group, never seen parts of frescos will be returned to their original places, while those already exhibited have been renovated from their badly demolished state. The reinforced concrete ceiling of the building built in the thirties stands on the site of the medieval White tower. The roof of the neighbouring spaces is damp because of structural faults but fortunately the chapel is not yet threatened. As far as I know, competent professionals have not even started to solve this problem. It is incomprehensible, that nowadays an international gem with such famous and valuable frescos can be left in such condition.

\section{Lábatlan}

The medieval Calvinist Church stands on top of the southern hill of the village. At first sight it seems like a medieval monument, but it was built in 1788 with its northern extension. Its medieval elements were restored between 2000 and 2001.

The nave, up to the framework, is from the medieval times. During the restoration works of the XIX century, its original windows were partly taken, partly walled off in order to establish a unified picture. Its southern gate has been split by a wall pillar. As the windows in the sanctuary were only walled off, its four original window frames could have been presented. On two of the frames even the start of the traceries can be seen. The 2001 restoration has managed to show its medieval elements as far as it is possible. Although in the internal area no medieval elements are visible, this is not possible without disturbing the

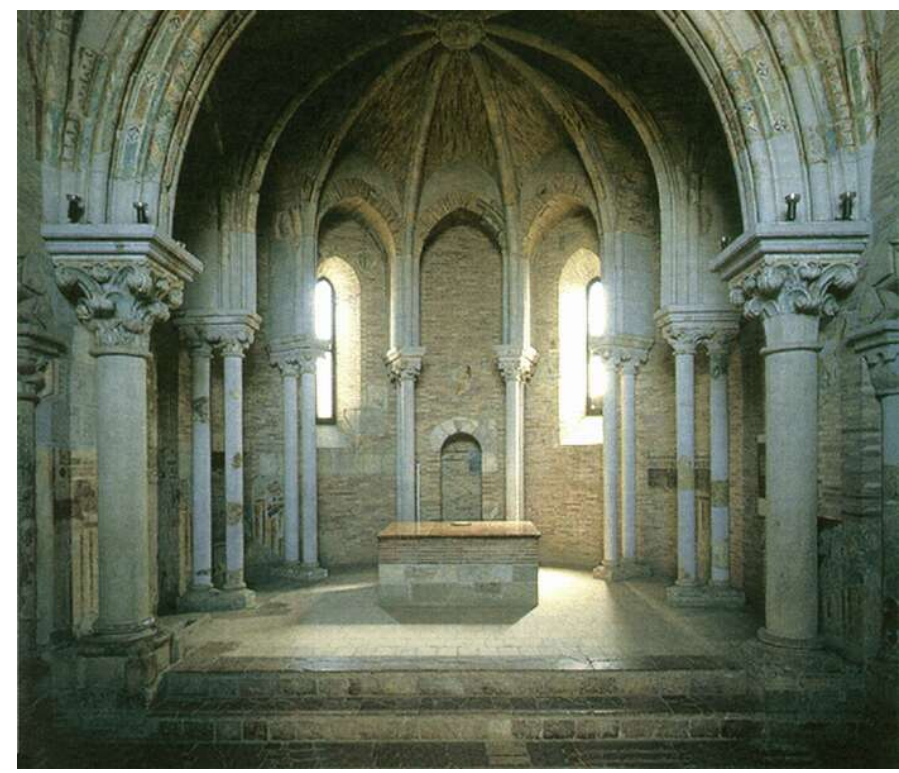

Fig. 5. The Castle Chapel of Esztergom

20th century interior. The outer medieval elements are separated with a rustic finish, since its uniformly coloured surfaces do not differentiate them from the latterly built parts. The armouring on the corners and on the buttresses of the original building shows the original space of the church. The transition between the whitewashed stone surfaces and the outstanding cut stones are more detailed in this case than in Csatka, although the authenticity of the appearance at the corners is questionable. The stressed frames of the new neo-gothic styled windows are out of place, just like the emphasised (by using different surfaces) medieval parts on the north wall of the sanctuary, from which differentiation from the other medieval wall parts is not evident. Having dispensed with these didactically disturbing elements, it remains very satisfying to see the monument in this condition. Unfortunately damp has resulted in frost damage to the base, which damages the aesthetic sight, however we should emphasis the well kept surrounding since it provides a suitable backdrop for the carefully kept monument.

\section{Neszmély}

On the basis of the ground-plan and the shape of this medieval church, it can be placed in the XIII-XIV century. Its original roman style elements are shown by its stubby tower and narrow loop hole styled windows, but its sanctuary is gothic. On the basis of Géza Máté's reconstruction plans, its medieval elements were restored in 2003.

The massive tower, up to the baroque styled roof, is medieval. Its cladding and its narrow loop hole styled windows are shown in their original places, the buttresses and window frames of the sanctuary are also presented in their original forms. The original medieval surrounding wall is a valuable part; in addition it emphasises the fortress character of the church. The internal area, just like in the case of Lábatlan, has no indication of its medieval origin although this is clearly shown by the external 


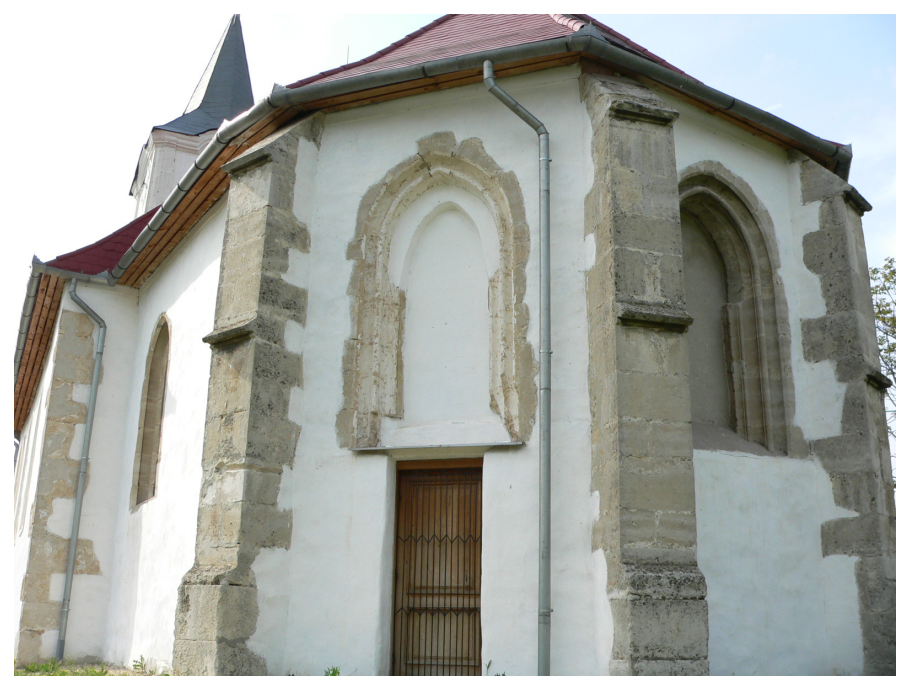

Fig. 6. The Church of Lábatlan

site. Of the emphasised medieval elements the northern double openings are didactically disturbing. Even though the restoration work was only a couple of years ago, it is already damp. In spite of the surrounding well kept garden it still looks neglected.

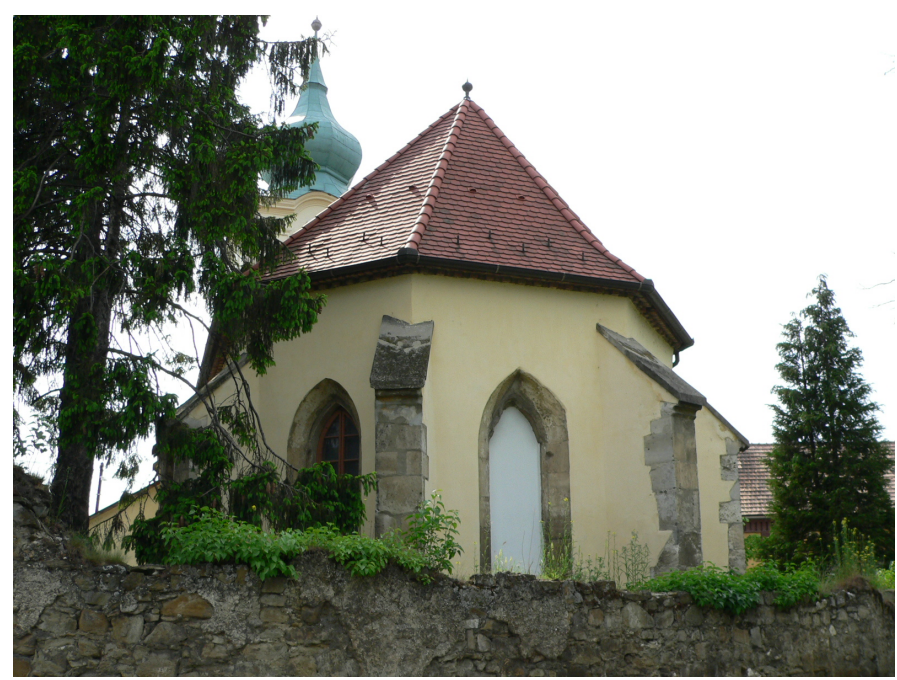

Fig. 7. The Church of Neszmély

\section{Tata}

The small sized chapel was formed by three sides of an octagon shaped sanctuary in 1350. In 1755 Jakab Fellner rebuilt the small medieval church into a chapel by keeping its sanctuary. The medieval appearance of the north-east side creates a picturesque sight, the monument keeping its original shape. The preservation clearly shows that until the roof, the buttressed sanctuary is medieval, while the window frames are gothic. The chapel and its surroundings are plain; the state of the building is good although the medieval sanctuary is damp.

The method of monument preservation is based on the same principals as in the case of the other presented buildings: separating the original mass from the latter built parts. I believe the preservation of the cladding is better in Bajna, where the wall surface was simply shown, while in the other cases it bulged under the whitewash. Apart from the case of Lábatlan the medieval elements on the facade do not coincide with the latter openings. There seems little point to the preservation of the remaining parts of the wall surface, as opposed to the case of Neszmély church. Their appearance does not strengthen the harmony of the façade, although generally we can say the overall appearance is authentically presented.

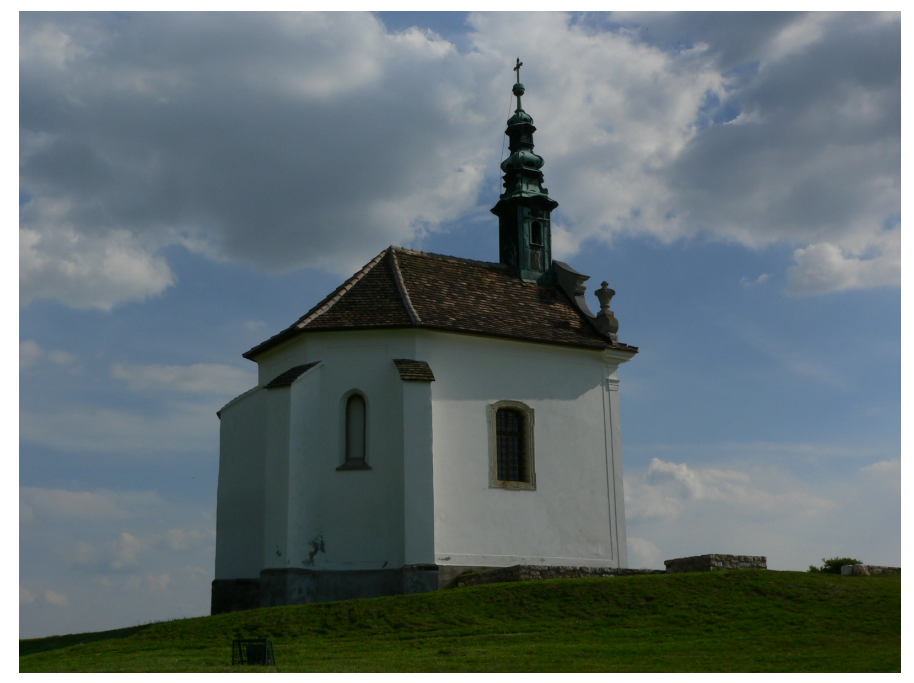

Fig. 8. The Medieval Chapel of Tata

Preservation of remains in the natural environment is easier than remains in an urban environment since it does not have to fit in with the later built uniform spaces. During monument preservation the designer is less forced to compromise. On the other hand, these monuments are not viable as sights without a suitable function. Moreover they are more sensitive than remains in urban areas, since these are not in evidence.

During renovation, didactical elements are more prominent. The enlargement of remains gives more opportunity for the renovator, but on the other hand it means a more complex architectural task. The elemental problem is to picture the original height of the remains. The extent of supplementation is another eternal question, especially with the consideration of authenticity. This aspect should be mainly considered during monument reconstruction since all works are the architectural style in line with the age of the presented remains. Jumping to conclusions is sometimes inevitable.

\section{Dömös}

Prince Álmos established the provostry of Saint Margit from possibly the royal hunting seat in 1107 . The building was demolished in the Ottoman Age although its remains certainly existed in the XVIII century. After the excavation, between 1988 and 1989 the OMF has reconstructed on the basis of Klára Nándori's plan, a part of the crypt.

Almost all the church and the attached quarter were demolished; the preservation of its ground walls has yet to be carried out. The south-east corner pillar remains give the original height 
of the provostry. The scientific restoration of the crypt without reconstructing the vaulting, provided an authentic preservation. Out of the presented capitals the in situ replacement of one of the most valuable carvings still has to be done. The preservation from 1989 is still viable - even though some parts are not in good condition and the reinforced concrete ceiling with glass oculus is broken in many places. The neglected aisle, presented by landscape architectural elements, is almost indistinct. The appearance of the remains is consistent, but the monument and its area needs further work. One of the most valuable parts of the reconstruction is that the former crypt area still works as a sacral space.

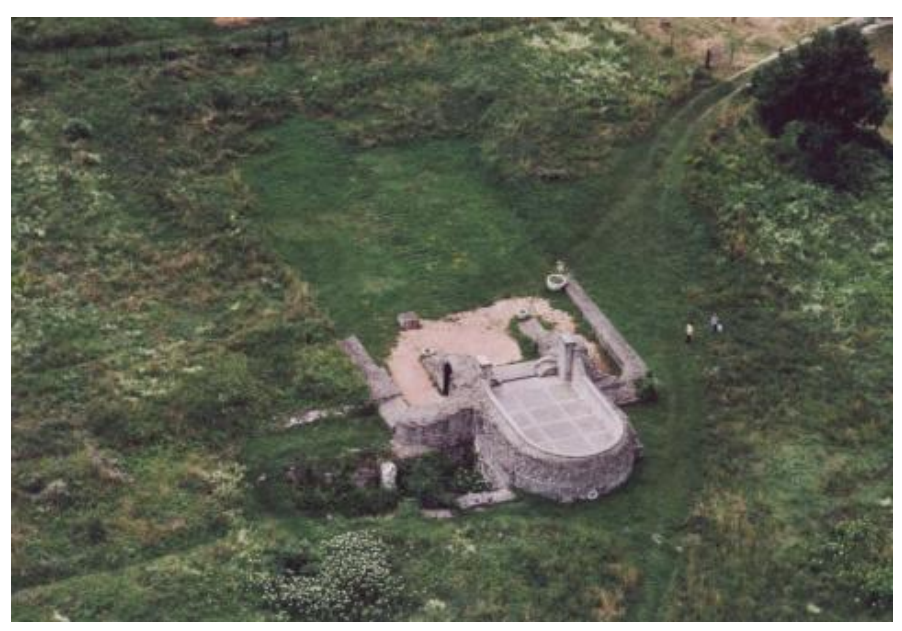

Fig. 9. The Ruins at Dömös

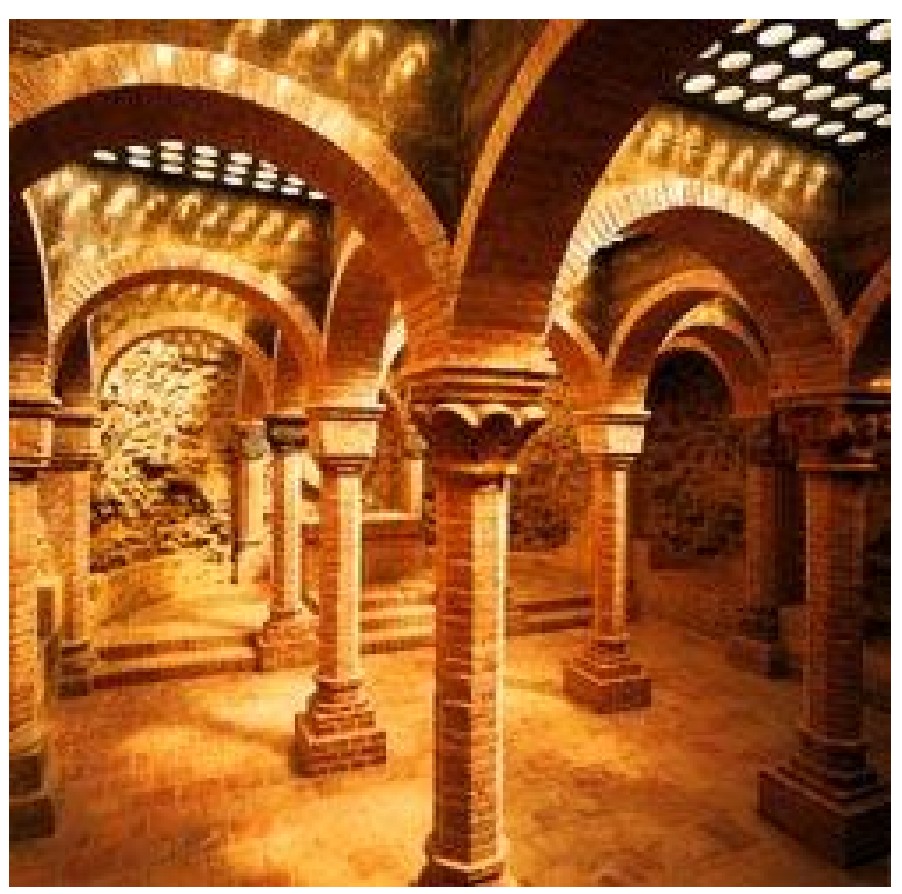

Fig. 10. The Ruins at Dömös

\section{Klastrompuszta (Kesztölc)}

Its medieval remains come from the Saint Cross founding monastery of the St. Paul order. The remains of the XIX century had disappeared by the XX century. István Méri excavated them in detail in 1961. During the process a small $80 \times 80 \mathrm{~m}$ gothic styled monastic church surrounded by stone walls, a monastery joining to the north side of the church and the remains of a smaller chapel were excavated. The excavation of the whole monastery has not yet been possible. It was built around 1250, then in the XIV or XV century it was rebuilt before finally in 1526 , the Turks burnt it down with many other monasteries in the Pilis.

There are no ashlars on the excavated ground walls although some parts of the chapel are fretworked. The more valuable ashlars were transferred to the National Museum. The remaining site is neglected; the presented ground walls are hidden behind greenery and grass. The wooden roof covering the chapel is in a life threatening state, the fence around the site has been damaged by curious tourists and it has not been maintained. It is a shame to see the founding chapel of the only Hungarian order in such a state; moreover it may hide the grave of blessed Özséb. The remains of Klastrompuszta are located near the settlement, as in Dömös, despite this no one seems to care about it. Maybe after the excavation it should have been recovered to preserve it.

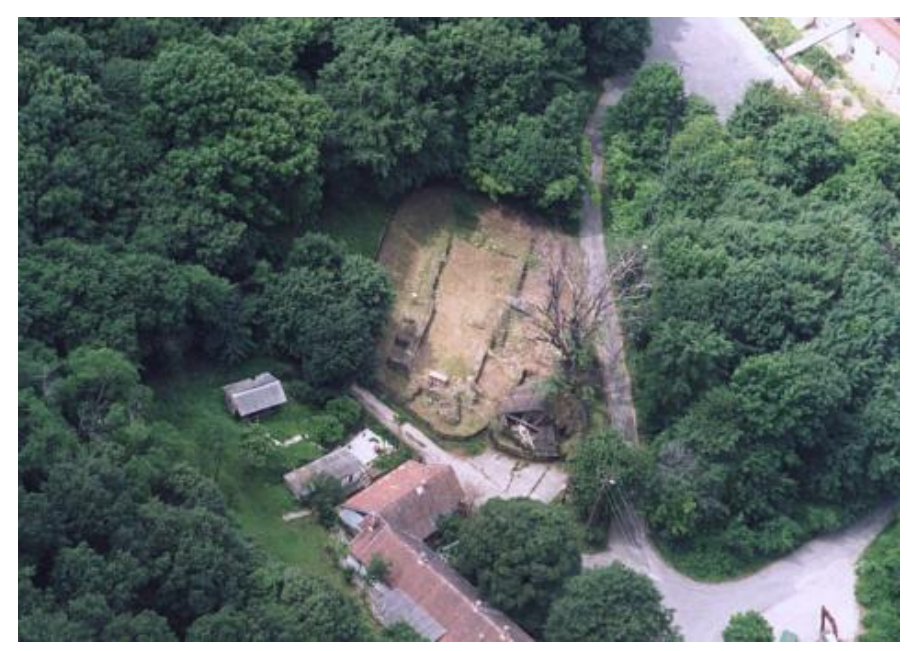

Fig. 11. The Ruins at Klastrompuszta

\section{Pilisszentlélek (Esztergom)}

The situation of the remains of this monastery of St. Paul is fortunately different. The history of Holy spirit monastery leads back to the XIII century, with it being demolished around 15261543. The first excavation was between 1928 and 1933, then in 1963. The present state of the remains was a result of the leadership of Dr. István Horváth archaeologist, and Dr. Ferenc Szeifert between 1985 and 1990.

There is a part from the carved rib of the shoulder of the vaulting on the north side area of the chapel, there are no ashlars in the remains. Only the walled ground walls depict the original building, although the height of the south-west wall corner remains and even the scaffold junction holes from the medieval walling procedure can be seen. By the instigation of local 
residents the monument preservation was established in 1985. The original, excavated stone material was used for crowning the wall. By 1975 two altars were restored moreover a consecrated relic was hidden under the marble stone of the main altar. In the last 30 years, every Pentecost morning a ceremony is held among the remains of the former church of the monastery. The monument is in a good condition since local residents take good care of it with continuous maintenance. The higher reconstructed walls depict the inner areas more effectively than the less completed foundations. The grass surface, instead of pebble stones, of the inner areas does not favourable display the internal and external sites. The completed works clearly show the remains and the authenticity of the site can not be questioned.

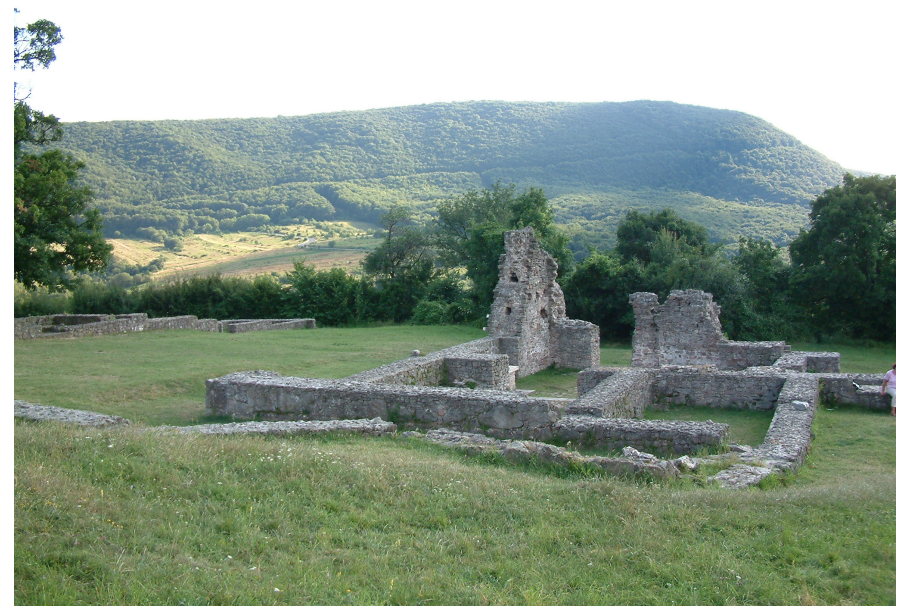

Fig. 12. The Ruins at Pilisszentlélek

\section{Vértesszentkereszt}

One of the most controversial monument preservations was the case of the Benedictine church and monastery ruins. Its reconstruction referred to as the "artificial stone mine" to express the exorbitant use of artificial stone, has never been finished. It is a god example of monuments located on the open road and standing without any function. Because of a lack of information, the remains are hidden in the middle of the forest. The monument's own lapidarium and all the carvings have been left behind.

The former two towered abbey church, established in the XII century, was in its prime in the XIII century. The monastery and the western vestibule were added to the church at the same time in the middle of the XIII century. In 1543, during the Turkish occupancy it was deserted. The building's value is hidden in its history, since the life of the monastery from the XII century up until the XVI century, can be followed through its ruins. Its detailed carved stone works are mostly in museums. Its most valuable local part is its richly carved western gate. The significant remains were renovated in 1994. At present, the monument is in bad repair and the remaining site is closed. At present no one takes care of its maintenance. Just as in the case of Klastrom- puszta, it is a shame to see one of our most significant medieval monuments and its site in such a neglected state.

The most disturbing element in the preservation is the nonunified composition of the renovated monument. The reconstructed vaults and the repeated renovation works do not give an authentic picture to the remaining preservation. The original and the reconstructed parts cannot be clearly distinguished in all cases, while the joint use of clinker brick and artificial stone replacement cannot be accepted didactically. This preservation points out the risks of excessive renovation in the reconstruction of remains. In addition to the used material, the lack of clarity is even more disturbing. Apart from the picture above, no information is provided for those visiting the location. These problems have to be solved in order to protect our monuments and make them accessible.

The presented examples show that without continual maintenance these sites will deteriorate after renovation. After the ceasing of their original functions no useful operational purpose has been developed. Next to Pilisszentlélek, the seasonally used (during the wedding season) Dömös crypt is a good existing example. In the case of remains, from which no detailed historical background information has been left to us, the renovation work can not create a spectacular site following its conservation. Such remaining preservations are condemned to obscurity, even by using different architectural tools. On the other hand in those cases where we work from detailed background information we should not make the mistake of excessive reconstruction as in Vértesszentkereszt, since chaotic didactical elements only serve to confuse visitors. Preservation only with architectural tools cannot show the monument's authentic historical background and since today's visual information displays are becoming more accepted, they should be used in our monument preservations. I am sure these monuments could appeal to more visitors with proper advertising, with the involvement of tourism or rather with the placement of information displays on the site. But intention is not enough, when the sites lack even maintenance.

Finally let us analyse the preservation of monuments in the urban environment. From Komáron-Eszergom County, only Esztergom provides examples. Most of Esztergom's churches have already been excavated, since the expansion of the medieval town was larger than that of the present day. The following analysis contains monuments from the historical part and from the suburban area.

\section{Esztergom: St. Cosma and Damian Church}

The church named after St. Cosma and Damian in Kovácsi, which is the part of medieval Esztergom, is an interesting example of the non-preservation of monuments. Its nave and sanctuary extend under the bank of Esztergom train station. It was firstly mentioned in 1270 , but it is also possible that it was built in the age of St Steven. The church was demolished in the XVI century. 


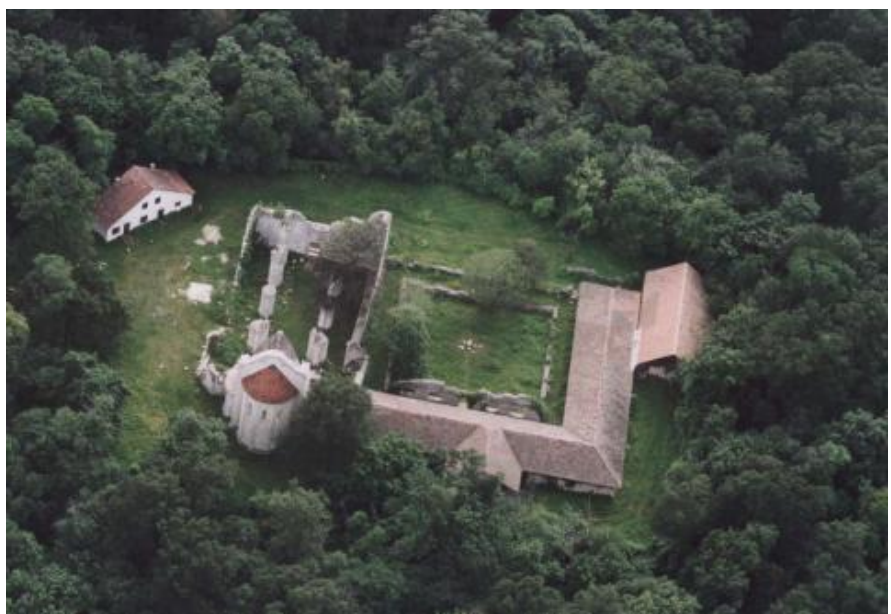

Fig. 13. The Ruins of the Abbey at Vértesszentkereszt

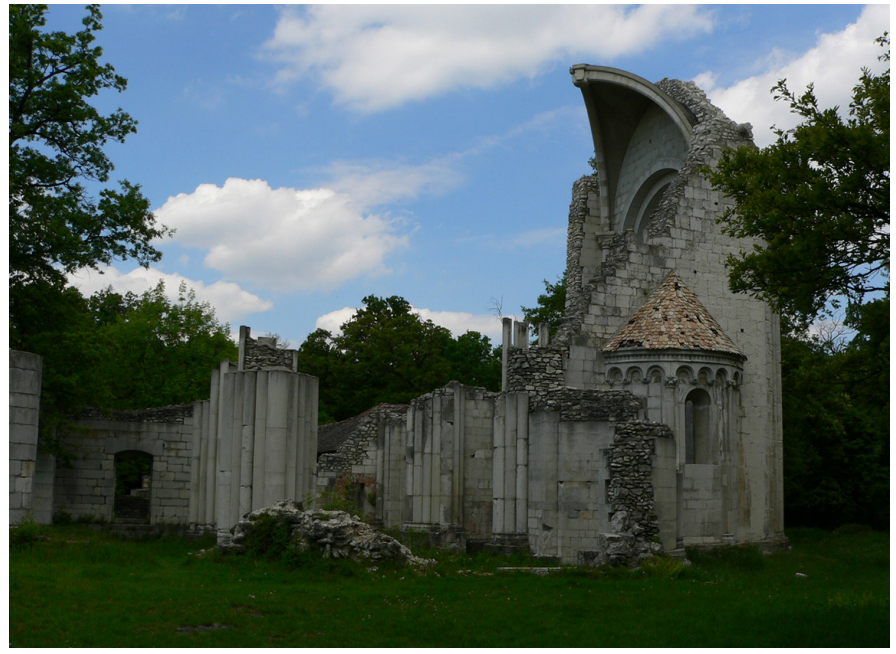

Fig. 14. The Ruins of the Abbey at Vértesszentkereszt

Even though most of the remains are still under the bank, the excavated ground walls stand out about 1 meter high although they cannot be seen as they are covered with undergrowth. Since there has not been any extended excavations so far, a possible extensive dig could reveal valuable building stone materials. On the basis of the already excavated building parts and the archaeological finds the preservation of the remains of this significant sized church is essential. Currently there is nothing to see at the site. Through the excavation and monument preservation of this roman styled church a remarkable southern gate could be created at the terminal of one of the busiest train lines in Hungary. Not to mention the resulting exciting theoretical and practical questions that its preservation may raise.

\section{Esztergom: The Saint Cross Parish Church and The Saint John Convent}

Some parts were excavated on the site of the demolished vicarage of the former Serbian church in the main street of Esztergom. The medieval St. Cross Church which maybe named after the St. Cross Convent of St. Johns, which stood outside of the medieval town, was built in the XIII-XIV century and was demolished in the siege of Esztergom in 1594-1595. In 2000 the Greek Catholic Church assumed the property of the old Serbian Church and in 2003 a new parsonage was built in the place of the ramshackle vicarage. During previous digs, the ruined walls appeared together with the "fireplace area" which is partly covered by a medieval brick pavement, both of which are exhibited in the cellar of the new building (work of István Horváth and Ferenc Mújdricza).

The possibility of visiting these ruins is limited and also relevant background information is missing, therefore the exhibited artefacts are poorly presented. According to the original plans the ground floor should be raised so the ruins can be seen from the street level. However due to the wired glass, presently it can only be viewed from the inside.

\section{Esztergom: St. Lawrence Church}

The significant medieval church, which stands on the north part of Esztergom's main square, was excavated two years ago, and was presented in 2006. The preservation of a ruin, which stands in the unified baroque-classicist square of a historical town, is very exciting in the field of the protection of monuments. The notorious case of the garden ruins of Székesfehérvár shows the possible pitfalls. In another article I have presented, the previous analysis and the possible preservation of the monument ${ }^{10}$ It is essential to compromise during the preservation of such monuments as we could see beyond the preservation of the built in and original medieval elements. Unfortunately this monument presentation owns almost all the mistakes that can be committed in the presentation of a ruin, that has been underground for hundreds of years 11

The colouring and the form of the preserved monument parts do not separate from the newly built panelling. The church is surrounded by a brick wall, which should have given the architect the opportunity to emphasise the preserved church by the partial reconstruction of the band of the encircling wall. Instead of this, the complex design of the pavement stops by the church and without any concept it continues with different incisions. The simple preservation of the ground wall is as much confusing as the reconstructed preserved walls and holes. Moreover, the markings in the panelling are useless without any information boards. I can only hope that these boards will be placed nearby at St. Lawrence's Church. If it is not going to attract people and become a live exhibit it will be nothing more than a few remains mentioned in this paper. Unfortunately, in this case this may well be the result.

\section{Summary}

Authenticity of preservation of our medieval architectural monuments mainly depends on practice, while the tools used depend on the condition of the original and excavated parts of the

\footnotetext{
10 Zsembery 1995. 12

11 Zsembery 2007. $\sqrt{10}$
} 


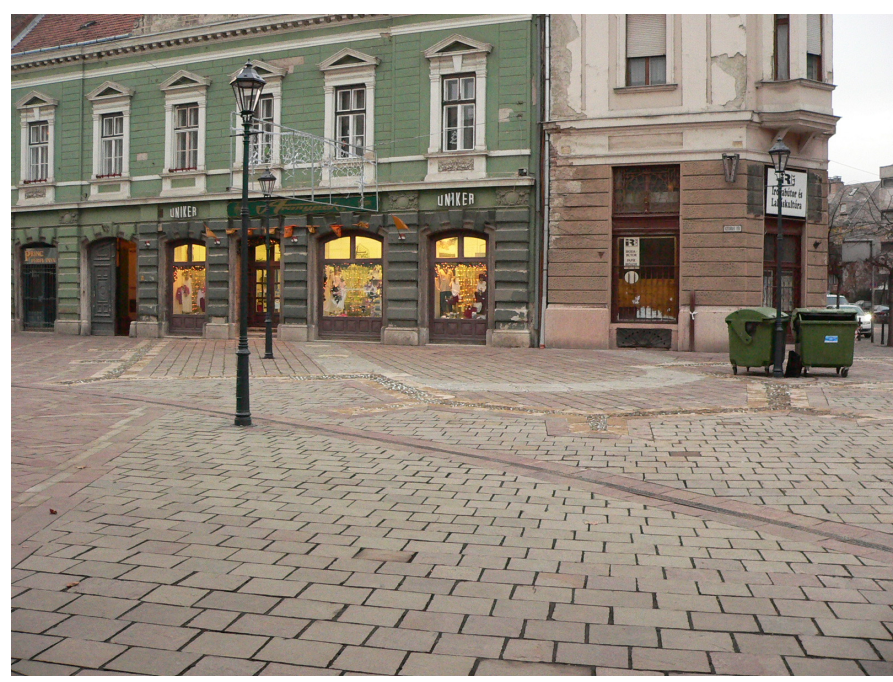

Fig. 15. The Presentation of St. Lawrence Church Esztergom

building. As a revision of our practical methods for the protection of monuments, on the basis of the above mentioned grouping, we should analyze the completed preservations in other parts of the country in addition to other buildings of different styles. As the previous comments show, there is plenty more to introduce in the future. The new constructional demands of developing cities provide continuing excavation, which in turn provides new information for our archaeologists. The preservation of such architectural monuments should be rationally considered. New demands create new situations, to which we have to find the best solution within the confines of the protection of monuments, especially the case of ruin preservation which requires new or rather an expanded variety of tools. The experiences of the last decades show the limits of such preservations which use only architectural tools. This should be expanded by different visual elements.

I believe didactics and authenticity will also be analysed within different dimensions.

\section{References}

1 Fejérdy T, Authenticity in monument restoration, Profession of building and architecture XXV (1995), 23-27. part 1-2.

2 Horler M, The Future of the Historical Environment and the Post-Modern Architecture, Hungarian Architecture 5 (1986).

3 Horváth I H, Kelemen M, Torma I, Archaeological topography of Hungary, Vol. 5, Akadémiai Kiadó, Budapest, 1979. Hereafter called MRT 5. in the article.

4 Mezős T, Theories and practices of the preservation of Roman architecture, Budapest, 1994. CScTheses, Manuscript.

5 Profession of building and architecture, Vol. XXV, Budapest, 1995. part 1-2.

6 Sedlmayr J, Beck Zs, Utilization of our 'dead monuments'- as we see it today, Protection of monuments 1/XLIV (2000).

7 Sedlmayr $\mathbf{J}$, Restoration and use of dead monuments for solutions of the '50's-'60's., Protection of monuments $\mathbf{1 / I}$ (1957).

8 , Authenticity in the protection of monuments.: Profession of building and architecture XXV (1995), 30. part 1-2.

9 , Preservation of different aged architectural values, ÉpítésÉpítészettudomány XV (1980), 367-386. part 1-4.
10 Zsembery Á, After exploration - lessons and questions in connection with the display of ruins, Protection of monuments 3/LI (2007), 331-336.

$11 \ldots$, Monumental situation of our medieval churches and monasteries in Komárom-Esztergom County, Architectura Hungariae VI (2004), no. 4, available at www. arch. eptort. bme.hu

$12 \ldots$, The research and the possibilities of monumental preservation of the medieval St Lorence Church in Esztergom, Profession of building and architecture XXXIII (1995), 83-109. part 1-2. 